\title{
Becoming Real in an Age of Shameless Lies
}

\author{
Sandra Lehmann
}

This article first examines the relationship between the postmodern deconstruction of representation and recent post-truth politics. It discusses to what extent the "hyperreality of simulacra" (Baudrillard) has become an instrument of power in recent autocratic policies. In return, it explores an alternative way of thinking of "the real." The basic thesis is that the real has its own force. Therefore, it is able to represent itself, that is, to reject certain signs as well as to demand them. However, the concept of representation proposed here does not fall back on the separation of subject and object typical for classical representation theory. Accordingly, the real is not to be understood as an objective counterpart to which we direct ourselves. Rather, it is a continuous founding process, more precisely, a surplus movement that lets us and all beings be. By genetically flowing through all things, it allows them to show themselves from themselves, thus counteracting the distortions tied to their appearing like a bad but unavoidable counterweight.

Postmodernism; Poststructuralism; Derrida; Foucault; Post-Truth Politics; Reality; Realization; New Continental Realism; Dynamical Metaphysics

Sandra Lehmann, Dr. Phil., Adjunct Professor at Webster Vienna Private University and External Lecturer at the University of Vienna. 2002 dissertation on the Czech phenomenologist Jan Patočka at the University of Vienna, 2006-2009 APART Fellow of the Austrian Academy of Sciences at the Franz Rosenzweig Center Jerusalem and the Institute for Human Sciences Vienna, 2014-2016 Assistant Professor at the Catholic Private University Linz. Several research and teaching stays at Charles University Prague, Palacký University Olomouc, and the University of Seville. Publications (selection): Eine Diskussion mit Markus Gabriel. Phänomenologische Positionen zum Neuen Realismus (ed.), Co-Editor: Peter Gaitsch and Philipp Schmidt, Vienna 2017, Die metaphysische Bewegung, Vienna 2014, Wirklichkeitsglaube und Überschreitung. Entwurf einer Metaphysik, Vienna 2011.

\section{Modernism and Postmodernity}

As Pericles Lewis suggests in his Cambridge Introduction to Modernism, the crisis of representation is in the first place an aesthetic problem. ${ }^{1}$ Since Romanticism at the latest, ${ }^{2}$ words and images have stopped simply depicting reality. Instead, they

1 Lewis, Pericles, "Introduction", in Lewis, Pericles (ed.), The Cambridge Introduction to Modernism, Cambridge, Cambridge University Press 2007, 3-10. 
become increasingly self-referential by reflecting their depicting function. That is, the meaning of words and images is no longer generated by an "external" reference, but rather by the fact that they refer to each other, and they in turn represent this relationship. Georg Lukács already diagnosed the problems associated with this in his Theory of the Novel of 1920: "We have invented the creation of forms: and that is why everything that falls from our weary and despairing hands must always be incomplete." 3

Poststructuralist theory - from Saussure to Barthes, Baudrillard, Derrida, Foucault and Lyotard, to name only the most prominent names - took up this specificity of modern literature and art most profoundly and continued it by transferring it to theoretical thinking. In this essay I will refer mainly to Foucault and Derrida. In The Order of Things, for example, Foucault explicitly places his archaeology in the line of Mallarmé's poetry. ${ }^{4}$ Along this line he advances to the actual core topic of his study, namely how language, in the course of the Classical age and up to the $19^{\text {th }}$ century, is no longer linked to signification, but rather to representation and discursivity; while in the $20^{\text {th }}$ century it also loses its connection to representation and becomes fragmented. ${ }^{5}$

Derrida, for his part, also maintains a strong relationship with literary modernism. Besides Mallarmé, his reference authors include Artaud, Blanchot, Celan, Char, and Kafka. Under the auspices of différance, he establishes that "signs represent the present in its absence; they take the place of the present;" $"$ in such a way that signs continually and persistently refer to more signs, while these signs again refer to yet other signs, and so on. Thus, what lies outside of signs, appears only as something withdrawn within signs referring to each other.

Within postmodern theory, the notion of the crisis of representation becomes even more complex because it offers both a comprehensive category of interpretation as well as serving as a critical instrument. As a category of interpretation, the "crisis of representation" not only transforms the problem of modern aesthetics into a formal problem that has to do with the theory of signs or discourse theory. Rather, it applies the aesthetic and formal theoretical problem to the modern way of life in general. From this perspective, the modern order of life is fundamentally characterized by a crisis of representation that extends from the individual relationship with the world to the political system of government. Baudrillard perhaps addressed this most consistently when speaking of a com-

2 First beginnings can already be found in the Spanish Classical period. Cervantes and Velázquez are well-known examples.

3 Lukács, Georg, The Theory of the Novel, London, The Merlin Press 1971, 33.

4 Foucault, Michel, The Order of Things, London. An Archeology of the Human Sciences, New York, Routledge 1989, 332-333.

5 Foucault, The Order of Things, 306-307.

6 Derrida, Jacques, Speech and Phenomena and Other Essays on Husserl's Theory of Signs, Evanston, Northwestern University Press 1973, 139. 
prehensive "substitution of the real with signs of the real" or of a "hyper-reality of simulacra."

By contrast, the "crisis of representation" serves as a critical instrument where it is used to question or even delegitimize modern subjectivity. One can think here of Derrida's criticism of "Western logocentrism" and "the metaphysics of presence." In return, he emphasizes language as a continuous process of shifts of meaning. Or one can think again of Foucault, who analyzes subjectivity as a specific game of signs organized by power. Subjectivity, once the promoter of the proud Enlightenment project, turns out to be a mere ensemble of knowledge, norms and self-practices that in itself lacks any substantiality. The historical a priori of discourse replaces the transcendental-subjective a priori, valid from Kant to Husserl.

\section{Ugly Grimaces}

It can hardly be denied that the "crisis of representation" was successful as a critical instrument, especially when it comes to processes of decolonization and the dismantling of gender hierarchies. Yet at present it may seem that this has come to an end, more precisely as if the critical forces of the crisis of representation have just exhausted themselves. Here I deliberately do not address the current situation of postcolonial studies or gender discourse, for this would require a differentiated discussion of its own. ${ }^{7}$ Instead, let us stick to the sphere of simple and relatively unmediated power, that is, the sphere of political power. In his 1995 essay Theorie des Ideologischen (Theory of the Ideological) Wolfgang Fritz Haug, who, from a Marxist position, remained critical of postmodern discourse throughout, speaks of the "age of digital processing" as the "Berlusconi age $[\ldots]$, in which the media power is finally preparing to diminish the reality of the referent into a connotation of the imaginary." ${ }^{\prime 8}$ In Haug's sense, one could say that with Berlusconi the crisis of representation comes true completely, for it has now seized power over the political and social status quo. The reason for this is that those who have the unconditional "will to power" have appropriated the crisis of representation and turned it into a strategy for their own benefit. They have learned that the only thing that matters is to impose signs - words and

7 As good examples see Seeßlen, Georg, "Semantical Healing", in: jungle.world 43/ 2015; Roedig, Andrea, "Über Begriffsdrachen", in: der Freitag.

8 Own translation. The German text reads: "Das Zeitalter der digitalen Bearbeitung [ist] das Berlusconizeitalter, in dem die Medienmacht sich anschickt, endlich den Referenten Wirklichkeit zu einer Konnotation des Imaginären herabzusetzen." Haug, Wolfgang Fritz, "Theorie des Ideologischen”, in: Bay, Hansjörg / Hamann, Christof (eds.), Ideologie nach ihrem 'Ende': Gesellschaftskritik zwischen Marxismus und Postmoderne, Opladen, Westdeutscher Verlag 1995, 47 (42-63). 
images, and their spectacular mélange - against other signs. There is no outside of signs, for the opposition between the signified and the signifier has long since been deconstructed. What may lie beyond signification is strangely reminiscent of the medieval concept of prime matter. Having no features of its own, neither impetus nor effect, it can be relentlessly deployed for power-strategic purposes. Following Giorgio Agamben's Homo Sacer project, we can say: this is the "mere life" of us all, this is our zoe.

Twenty years after Haug's essay, Berlusconism has reached the heights of world politics. In line with his politics of "alternative facts," US President Trump has ceased to follow the imperative of credibility, respectability, and decency, which used to be binding for the heads of representative democracies. Other autocrats such as Putin or the boards of the major sports associations IOC and FIFA have never cared about democratic procedures anyway. However, their audacity has also reached a new level. Just think of how the IOC and the Russian state power under Putin dealt with the Russian doping problem during the 2014 Winter Olympics in Sochi; not to mention other cases of ubiquitous corruption. What is disturbing is that the lies of these actors are well documented in the media and yet they continue to act as if nothing had ever been documented. In continuation of another motive from Agamben, this time from his commentary on St. Paul's Letter to the Romans, one can speak here of a suspension or depositioning (Entsetzung), namely of a depositioning of lie (Entsetzung der Lüge): Trump and Putin and others lie as if they were not lying; only that this depositioning has nothing to do with a messianic crisis of power. On the contrary, it serves as an unreserved exhibition of entirely mundane power with all its presumptuousness and ruthlessness. Therefore, linguist Ruth Wodak is right when she states that our age is less a "post-factual age" than an "age of shamelessness": "Shameless lies are brought into the world [...] without negative sanctions, even without apologies." In other words, we are in a situation where truth claims are simply ignored, because apparently, they can be simply ignored.

It would undoubtedly be too simplistic to assume (as some do or have already done) that poststructuralism is the ideology of neoliberal capitalism, which in theory dismantles all obligations in order to unleash the unrestricted play of powers and forces in practice. Nevertheless, it seems that poststructuralist discourse has contributed to the age of shamelessness by rejecting, like the current autocrats, all claims to truth in favor of a practice of depositioning. I am thinking here once again of Derrida's early "affirmation of the play of the world [...], the affirmation of signs without fault, without truth"10, as well as his later, often repeated proclamation of the abysmal separation from truth, according to which every presumed truth is at best a deceptive surface phenomenon. One can also

9 Wodak, Ruth, "Die Medien haben Kurz mitgemacht”, in: FALTER 51-52/2017, own translation.

10 Derrida, Jacques, Writing and Difference, London / New York, Routledge 2005, 369. 
think of Foucault's replacement of truth by "games of truth", which are not about "the discovery of true things but the rules according to which what a subject can say about certain things depends on the question of true and false." ${ }^{\prime 11}$ But what about those subjects who consciously prefer the false to the true? From Foucault's perspective, there is nothing to prevent the answer: they're not lying, they're just changing the rules of the game on their own accord. In a remarkable way they resemble the subject of Foucault's later philosophy, a subject that transforms itself in such a way that "it cannot find itself again in a form that can be described as the effect of an external power." ${ }^{\prime 2}$ Don't we meet here exactly the contemporary autocrats who, after many personal transformations, are finally independent of any external power? One might think of the winding lives of a Putin or Trump. There is much to suggest that characters like these two have every right to feel like the sovereign masters of an "aesthetic of existence;" hardly according to the intention of postmodern theory, but still according to the result.

Faced with these masters of the world and their shameless lies, I believe it is time to reinvigorate a discourse of truth. Truth here is primarily not to be understood as a formal-semantic problem, or a matter of truth-apt statements, but as something that concerns the core of human life. In other words, from the perspective suggested here, truth is only in a secondary sense an epistemological category but basically an ethical one.

This is actually not so far removed from Foucault's "parrhesia." However, I would like to add a material element, while Foucault's approach remains merely formal. Since truth has to do with what is really the case, a discourse of truth is inevitably linked to a discourse of reality. Indeed, one can say that truth can only be thought of under the condition of a strong notion of reality. Reality is to be understood accordingly as that which exceeds all relativizations.

In the following I would like to outline elements of such a discourse that progressively binds truth and reality together. In contrast to poststructuralism, the basic thesis is that the real cannot be substituted by signs. Rather, according to this approach, the real has its own force; because it has its own force, it is able to represent itself, i. e. to reject certain signs as well as to demand them. The ethical dimension of truth relates to this claim for appropriate signs. There is an imperative of the real. The real demands us to be true; true in a threefold sense: in the sense of fidelity, precision, and sincerity.

Note that from this perspective, the representation - "true signs" - that the real demands of us lies before the separation of subject and object, which applies to classical representation theory. Accordingly, the real is not to be understood as an

11 Foucault, Michel, "Foucault", in: Foucault, Michel, Essential Works, Vol. II, New York, The New Press 1998, 460.

12 Saar, Martin, "Die Form des Lebens. Künste und Techniken des Selbst beim späten Foucault”, in: Foucault, Michel, Die Ästhetik der Existenz. Schriften zur Lebenskunst, Berlin, Suhrkamp 2007, 321-343, here: 336. Own translation. 
objective counterpart to whom we direct ourselves. Rather, we should conceive of it as a movement that lets us be, just like all things, by leading us beyond what we are at present in a dynamic vertical sense. In fact, the real is so little at our disposal that in the final analysis, it could be said that false signs make us perish in the flow of the real, while true signs will save us.

\section{The Emperor's New Clothes}

Let us start with an exemplary case, namely Hans Christian Andersen's fairy tale The Emperor's New Clothes, which is actually a parable. There's an emperor who loves beautiful clothes. One day two fraudsters come to the city and promise him clothes of exquisite quality. However, they say whoever is stupid or unfit for their office cannot see the clothes. The emperor orders the clothes immediately, not least to test his highest officials. The fraudsters begin to weave the supposed clothes, but they take the silk provided for this purpose themselves and weave with nothing. Since the clothes consist of nothing, neither the officials, who are to supervise the progress of the work, nor the emperor himself can see the clothes. But since neither of them wants to be considered stupid or incapable, they don't admit this. Rather, they pretend to be enthusiastic about the beauty of the clothes. To break the spell of deception, which is supported by everyone, it finally takes a little child; "the voice of the innocent [den uskyldiges røst]," as Andersen writes. During the public presentation of the emperor's new clothes, the child exclaims: "But he has nothing on at all [men han har jo ikke noget på.]!" Andersen's fairy tale ends with a literal and very democratic uncovering of the logic of power: “'But he has nothing on at all!' cried the whole people at last. That made a deep impression upon the emperor, for it seemed to him that they were right; but he thought to himself, 'Now I must bear up to the end.' And the chamberlains walked with still greater dignity, as if they carried the train which did not exist."13

Andersen's fairy tale very clearly refutes Foucault's assumption that it is games of truth that decide what is true or false and what exists or does not exist accordingly. Of course, the fraudsters who weave with nothing and pass off the result of their weaving art as something are playing a game of truth. They create a situation of speech - of "veridiction", as Foucault calls it - in which the emperor, his officials and at first also the people declare existent what does not exist. Yet this truth game, which is actually about deception and self-deception, cannot be persevered. However, the reason is not, as the late Foucault apparently assumes,

13 In Andersen's original text, it reads: “'Han har jo ikke noget på!' råbte til sidst hele folket. Og det krøb i kejseren, thi han syntes, de havde ret, men han tænkte som så: 'nu må jeg holde processionen ud'. Og så holdt han sig endnu stoltere, og kammerherrerne gik og bar på slæbet, som der slet ikke var." Andersen, Hans-Christian: The Emperor's New Suit. 
that individual members of society change in such a way that the rules of the game of truth also change. Rather, the situation changes abruptly in Andersen's fairy tale and through an intervention from the outermost edge of society, where other games, not truth games, are played. From the perspective of the child, the socially constituted meanings are irrelevant. They collapse in on themselves and the truth emerges: the emperor is naked. There are no new clothes.

There can be no doubt that the case from Andersen's fairy tale is a very simple case, and there are undoubtedly cases that are not so easy to resolve. The question of what gender designations really refer to is a good example. It is therefore advisable to distinguish exactly from case to case. Nevertheless, there seems to be an excessive remainder, an overflowing surplus of the real, even in cases that are overdetermined by a game of truth, so to speak, and where meanings seem to result solely from discursive construction. For instance, and to stick to the example, when people cannot bear their gender role, when they suffer from it, and at least know "I'm not a woman/I'm not a man."

Let me pursue this thought. In fact, the question of the real seems to be exactly about this surplus. It is something that evades signs and meanings; yet it aims at the sign, the true sign, to show that it itself, the real, is there. The next section will focus on three aspects of a phenomenology of the real to support this notion.

\section{A Short Phenomenology of the Real}

I speak of a phenomenology of the real because, following Heidegger's early fundamental ontology, or hermeneutic phenomenology, I assume that what we are dealing with, the "things" or phenomena, is "that which shows itself in itself" 14 and accordingly "shows itself from itself." 15 It is another matter that phenomenological thinking, including Heidegger, has not adequately addressed the selfgiving of phenomena for a long time. Jean-Luc Marion's writings have seminal significance not least against this background.

Three aspects then. First aspect: As noted, under the wrong discursive conditions, the real appears as an excessive remainder, an overflowing surplus. A primary indicator of this is that the real appears as resistance against what misses the real itself, be it the wrong discourse or the wrong interpretation or the wrong sign. It follows from this resistance that the wrong is always connected with an effort. The wrong must constantly assert itself against the resistance of the real, and this constant coercion to ignore what is real is eating away at the wrong or at those who support it. One could certainly show this, albeit in a more detailed discussion, for the wrong that arises from lack of wit or inattentiveness. The simplest and clearest example, however, is exactly what interests us, namely lies.

14 Heidegger, Martin: Being and Time, Oxford, Blackwell 2001, 51.

15 Heidegger, Being and Time, 58; my emphasis. 
In this case we can even refer to Nietzsche, who wrote about the lie in Human, All Too Human: "Why do people almost always tell the truth in everyday life? Certainly not because a god has forbidden lying. But [...] because it is easier; for lies inquire inventiveness, dissimulation, and memory [...] anyone who tells a lie seldom notices the heavy burden that he has taken on; in order to maintain a lie, he must invent twenty others." 16 The force of the real extends to the point where lies make people sick. People suffer psychophysically from lies, especially if they support the lies against their own will. Or, to name another case, political tyranny with its dishonesty and compulsion to conceal destroys entire societies.

The resistance of the real is important not least because it contradicts the poststructuralist reductionism of all that concerns us into the signifier. The resistance of the real against the lie shows: something is pervading our lives, which is not constituted by signs. Rather, it works independently in the signs, also in such a way that it works against the signs when they distort it. The trace is not, as Derrida suggests, "the origin of the origin" of what was actually never there. ${ }^{17}$ Rather, it indeed points to something; something one can even call the "thing itself."

However, - the second aspect - how should we understand the "thing itself"? In fact, I agree with Derrida and others that a simple metaphysics of presence is misleading. This refers both to the notion that our ideas are based on fixed things or substances as well as that the real is what is fully indicated by concepts. I will expand on the relationship of the real to concepts in the last section. Let us note at this juncture that the resistance of the real nevertheless points to the fact that what appears to us - the phenomenal, the phenomena - has a "self". On the one hand, the self stands for the fact that what is given to us - or rather, what has given itself to us - is not arbitrary or interchangeable. An example ex negativo: Only a bad language, the language of cliché, describes one phenomenon in such a way that it cannot be distinguished from the other. On the other hand, the resistance of the real indicates that hermeneutics is limited. One phenomenon cannot be all that an interpretation requires of it. Rather, there is a limit to what a phenomenon can be; even if "we do not even know what a body can do" 18 or what the limit of the phenomenon is. The limit is determined by the phenomenon itself. To refer once again to Andersen's parable: what is woven of nothing will never be a dress; even if there may be ways - ways of seeking one's own advantage, rather than artistically showing the invisible - to stage it as a dress.

16 Nietzsche, Friedrich: Human, All Too Human. A Book for Free Spirits, The Complete Works of Friedrich Nietzsche, Vol. 3, Standford, Standford University Press 1995, 57. Tellingly, Nietzsche's subsequent view on children's relationship to lies is less positive than that of Andersen.

17 See Derrida, Jacques: Of Grammatology, Baltimore / London, John Hopkins University Press 1976, 61.

18 Deleuze, Gilles: Spinoza: Practical Philosophy, San Francisco, City Lights Books 1988, 17-18. 
One can conclude from this that the self of phenomena is characterized by its own insistence. In other words, phenomena insist on themselves, while giving themselves. They can never be completely appropriated. This insistence also implies that phenomena can hold out, that they cannot be destroyed by false truth games. Rather, they can only be repressed, covered up, or suppressed.

Accordingly, one could say that phenomena in the wake of insistence also have a certain consistency and continuity. Thus, even if it is not true that phenomena are based on or refer to fixed substances, one can speak of them as specific somethings in the sense that phenomena appear to us as manifestations of the history of a consistent movement.

If it was said above that the real is a movement that points us, or rather, beings in general beyond themselves in a vertical sense, this can be specified here. The reality of something is the movement of its realization - in constant struggle with the distortions that are part of the process of appearing. The future of this movement is open to us, yet it is not arbitrary. That is, it is the future of this appearing thing, of this very phenomenon. However, the impulse for how the phenomenon appears lies with the phenomenon itself. It is the impulse of its realization beyond itself. Therefore, we can never dispose of a phenomenon.

This implies that a phenomenon may suddenly turn out to be different, even in a radical sense. The real brings about an abundance of consistent yet changing, even eventful phenomenal effects that neither we nor, for that matter, anonymous systems of signification can ever fully exploit. While for us this is an indication of the surplus character of the real, every event, even unforeseen transformation, is consistent within the framework of the history of realization of the real.

The third aspect is related to this. It would not be enough to understand the insistence, consistency and continuity of phenomena purely negatively as something that shows itself in resistance against false truth games. Rather, phenomena have their own impetus. Even on the level of immediate aisthesis, which is poor in interpretation, it can be seen that phenomena are guiding action on their own initiative. Their form and material imply a project (Entwurf) that can considerably expand our possibilities for action. Yet it also specifies what these possibilities look like. Note in passing that Heidegger's famous Zeuganalyse of Being and Time significantly ignores this point because it places too much emphasis on human practical circumspection (Umsicht); a point to which neo-realist authors such as Markus Gabriel or Graham Harman have also referred. ${ }^{19}$ However, if we can reasonably assume that phenomena have their own impetus and project, and that they demand certain actions, it is obvious that they also demand certain signs; signs that do justice to them. It is because of this demanding impetus of phe-

19 See Gabriel, Markus: “Is Heidegger's 'Turn' a Realist Project?”, in: META: Research in Hermeneutics, Phenomenology, and Practical Philosophy, Special Issue, 2014, 44-73; Harman, Graham: Tool-Being. Heidegger and the Metaphysics of Objects, Chicago / La Salle, Open Court 2002. 
Becoming Real in an Age of Shameless Lies

nomena that words can have liberating or even redemptive power. In the following I will speak of the solving (lösende) quality of words, which echoes both their liberating and redemptive power.

\section{The Solving Word and the Dynamics of the Real}

Again, we can think back to Andersen. The cry of the child "he has nothing on at all" abruptly ends both deceit and self-deception. However hard the chamberlains try to keep up the lie - no matter how much dignity they show while carrying the non-existent train - the real has found the solving word (das lösende Wort). Importantly, the searching for and finding of the solving word originates from the real itself. Andersen shows this in an exemplary way. The child pronouncing the solving word has not been looking for it. Precisely because it is innocent, as Andersen writes, it reveals the real without claiming anything, let alone the truth of truth games. Accordingly, one could say that the child is not a subject of speech. Rather, it is the medium of the searching of the real for the solving word. This is essential to distinguish it from Foucault's veridiction.

My reservations concerning the traditional metaphysics of presence can also be specified by recourse to the solving word. The crucial point seems to be that it is not a concept. Concepts resemble signs in that they treat phenomena as substitutable. Concepts, for their part, apply a general form to phenomena that turns them into cases among others. By contrast, the solving word refers to phenomena as individuals that cannot be substituted. Consequently, the solving word is not supratemporal as concepts pretend to be. Rather, it is related to the real, insofar as the real is coming to be in time. The solving word gives presence to the phenomena in the sense that they can show themselves from themselves. Thus, it releases them from those games of truth that distort them. However, this is still related to temporality. The solving word indicates that phenomena can be transient and yet truthful. Phenomena are truthful in that, in finite situations, they can find the signs that allow them to show themselves from themselves.

This relationship of signs, phenomena and time also has consequences for the relationship between the solving word and games of truth. The solving word never completely leaves the truth games behind. It takes place among them and thus it remains revisable; not because it becomes untrue, but because it itself creates a new truth game. To put it more simply: The solving word opens a different view of the world, it creates a new situation. Yet in this new situation there will be other distorted realities searching for the true sign or solving word. There is no complete transparency under the finite circumstances in which we live. However, this is not to relativize reality and truth. It simply means that there is no total, all-encompassing representation of the real.

Reality is a surplus movement (Überschussbewegung), thanks to which single phenomena can show themselves from themselves as undistorted; that is, against 
the distortions that are the rule in a world without complete transparency. This also implies a demand on us that we can speak. The real calls for the transformation of ourselves in such a way that we move into the position of the medium; that we take on passage-like agency, creating space for phenomena to show themselves from themselves. We are called to devotion to phenomena, to accuracy and precision, while we are dealing with them. The point is to enter into the dynamics of the real under conditions that tend to be dominated by the fascination of that which is woven of nothing, of empty signs, in a word, the unreal. We must begin creating processes of the real.

\section{References}

Deleuze, Gilles: Spinoza: Practical Philosophy, San Francisco, City Lights Books 1988. Derrida, Jacques: Of Grammatology, Baltimore / London, John Hopkins University Press 1976.

Derrida, Jacques: Speech and Phenomena and Other Essays on Husserl's Theory of Signs, Evanston, Northwestern University Press 1973.

Derrida, Jacques: Writing and Difference, London / New York, Routledge 2005.

Foucault, Michel: "Foucault," in: Foucault, Michel, Essential Works, Vol. II, New York, The New Press 1998, 459-464.

Foucault, Michel: The Order of Things, London. An Archeology of the Human Sciences, New York, Routledge 1989.

Gabriel, Markus: “Is Heidegger's 'Turn' a Realist Project?”, in: META: Research in Hermeneutics, Phenomenology, and Practical Philosophy, Special Issue, 2014, 44-73.

Harman, Graham: Tool-Being. Heidegger and the Metaphysics of Objects, Chicago / La Salle, Open Court 2002.

Haug, Wolfgang Fritz: "Theorie des Ideologischen", in: Bay, Hansjörg / Hamann, Christof (eds.), Ideologie nach ihrem 'Ende': Gesellschaftskritik zwischen Marxismus und Postmoderne, Opladen, Westdeutscher Verlag 1995, 42-63.

Heidegger, Martin: Being and Time, Oxford, Blackwell 2001.

Lewis, Pericles: "Introduction," in Lewis, Pericles (ed.), The Cambridge Introduction to Modernism, Cambridge, Cambridge University Press 2007, 3-10.

Lukács, Georg: The Theory of the Novel, London, The Merlin Press 1971.

Nietzsche, Friedrich: Human, All Too Human. A Book for Free Spirits, The Complete Works of Friedrich Nietzsche, Vol. 3, Stanford, Standford University Press 1995.

Saar, Martin: "Die Form des Lebens. Künste und Techniken des Selbst beim späten Foucault", in: Foucault, Michel, Die Ästhetik der Existenz. Schriften zur Lebenskunst, Berlin, Suhrkamp 2007, 321-343. 


\section{Internet Sources}

Andersen, Hans-Christian: The Emperor's New Suit, available here: http://mennta.hi.is/ vefir/danska/rejselaere/materiale/HC\%20Andersen/Kejserens.htm, English translation follows this link: http://hca.gilead.org.il/emperor.html [September $25^{\text {th }}, 2018$ ].

Roedig, Andrea: “Über Begriffsdrachen”, in: der Freitag, available here: https://www. freitag.de/autoren/der-freitag/ueber-begriffsdrachen [June $19^{\text {th }}, 2018$ ].

Seeßlen, Georg: "Semantical Healing”, in: jungle.world 43/2015, available here: https:// jungle.world/artikel/2015/43/semantical-healing [June 19 ${ }^{\text {th }}, 2018$ ].

Wodak, Ruth: "Die Medien haben Kurz mitgemacht", in: FALTER 51-52/2017, available here: https://www.falter.at/falter/rezensionen/buch/712/9783902968104/politikmit-der-angst [June 19 ${ }^{\text {th }}, 2018$ ].

Sandra Lehmann, Department of Philosophy, Faculty of Philosophy and Education, University of Vienna, Universitätsstraße 7, 1010 Vienna, Austria, e-mail: sandra.lehmann@ univie.ac.at

Citation: Lehmann, Sandra: "Becoming Real in an Age of Shameless Lies", in: Appel, Kurt / Raschke, Carl (eds.): The Crisis of Representation (J-RaT 2018 / 2) pp. 332-343.

Datum der Publikation: 21.01.2019 